\section{CURIOUS FISHES OF THE DEEP SEA}

That one animal can devour another twice its own size, at a single swallow, is a statement that may seem to the uninformed to be as incredible as any fish story ever invented. Nevertheless, it is true of certain tishes. So far as known, such fishes are inhabitants of the deep seas, where utter darkness perpetually prevails, with an unvarying temperature almost as cold as ice, and a pressure ranging, according to depth, from a quarter to three or four tons upon every square inch of their body surface.

The deep sea is commonly regarded as commencing where the rays of sunlight cease to penetrate, which is estimated to be less than twelve hundred feet below the surface, and may extend to twenty times that distance, or even much more, down to the bottom of the ocean. Fishes have been dredged from below twelve thousand feet. Under such diverse conditions of life, we would naturally expect that their respective in habitants would present considerable difference in their structural particulars, and also in their habits. To considerable cxtent such is the case. But in this connection we meet with some surprises of quite a remarkable character, and which seem to oppose the curren evolution theory. For example, instead of the total darkness invariably abolishing the organs of vision by disuse, we find that the deep-sea fishes commonly possess eyes, while only a few are blind. In this connection it may be remarked that some surface-water in habitants are also blind. There are evidences, however, which appear to be characteristic qualities of deep-sea fishes, namely, weak connective tissue and extremely delicate fin muscles, indicating still-water conditions also thin fibrous bones, full of cavities, indicating highpressure conditions. While these peculiarities are doubtless well adapted for deep-sea life, an idea of their unfitness for superficial waters may be gleaned from the following extract from Dr. Alcock's recent book, which records his observations as naturalist to

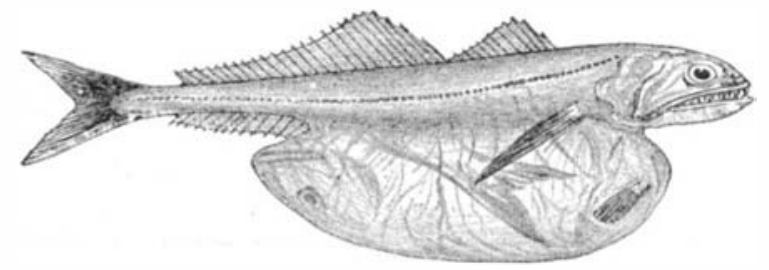

CHASMODON NIGER (CARTER)

Fish 65/8 inches long containing in its stomach a fish $101 \frac{1}{2}$ inches long.

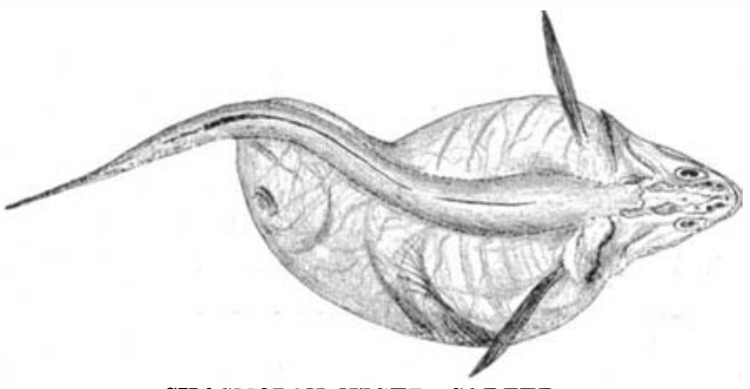

CHASMODON NIGER (CARTER).

Top view of $65 \%$-inch fish with 101/-inch fish in its stomach.

the ship "Investigator" of the British navy. He says : "When a deep-sea fish is brought to the surface, how gradually and carefully soever, its bones are often like so much touchwood and its muscles like rotten pulp, while its eyes are burst from its sockets, and its viscera are often blown out of the body cavity by the expansion of the air bladder." It frequently happens that deep-sea fishes are found floating helplessly on the surface of the ocean, with large prey in their stomachs. Their appearance under these circumstances is accounted for by the efforts of their struggling victims to escape from their jaws, causing them to ascend beyond the horizontal zone which they usually inhabit. "This explains," observes Gun ther, "the fact that all the specimens known of Saccopharynx and Melanocetus-deep-sea Chiasmodus-were found with large fishes in their stomachs. The specimens swallowed were found in each case to be in a very early state of digestion."

Yet, in a general way, the structural forms of deep-sea fishes are identical with certain fishes familiar to surface waters, so that they are regarded as simply being adaptations of existing surface-water species, and not a special order by themselves.

It appears that many surface-water species stray into the deep seas; and while the shift from the one environment to the other is necessarily through a graded course, it is a mystery why any should ever have re mained under such unfavorable conditions.

Such a naturalization would seem to be a reversal of the most natural kind of selection, and there appears to be no theory to account for it.

In addition to the extraordinary rapaciousness of certain deep-sea fishes, there are many which are re-

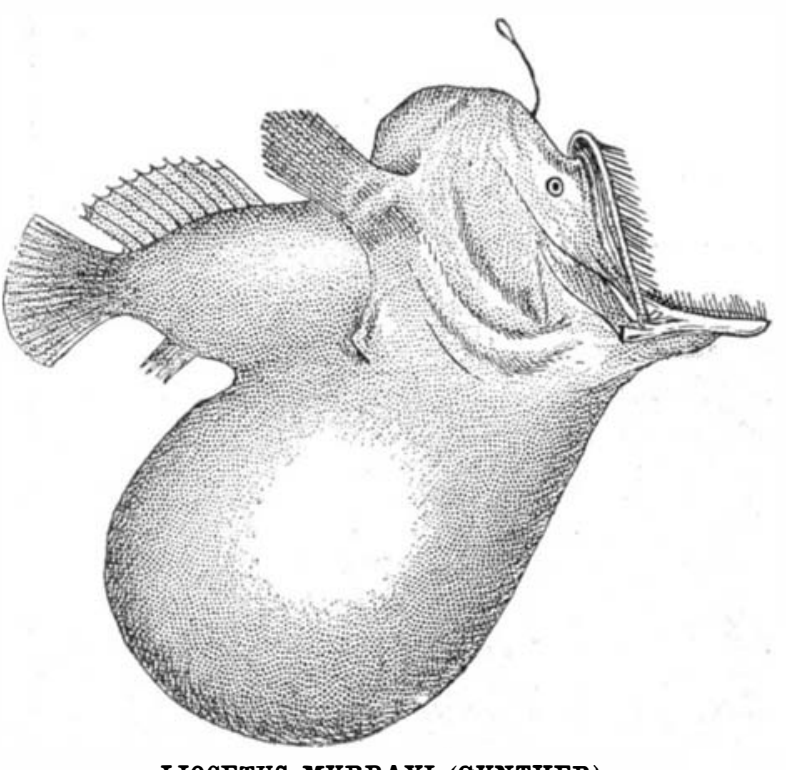

LIOCETUS MURRAYI (GUNTHER)

A fish less than 4 inches long with a fish in its stomach $7 / 2 / 2$ inches long.

markable for their possession of illuminating organs. These attributes are not limited to deep-sea fishes, but among these fishes there are examples which eclipse anything elsewhere found. With the exception of the so-called "lures" of deep-sea fishes, their luminous organs appear to be modified mucous glands, which produce the "phosphorescent" light. These are said not to exist in the small-eyed fishes, which, instead, possess sensitive organs of touch; and while they are commonly absent in the blind fishes, some possess them highly developed, as in the Benthobates moresbyi. But illuminating power may exist without phosphorescent glands. For example, in the Leptoderma affinis, which has eyes resembling goggles, there are no phoswhich has eyes resembling goggles, there are no phos-
phorescent glands, but its skin gives off a luminous bloom. In the Ipnops, the two eyes are flattened out, covering the whole top of the head, and are luminous in life. In the Orthoprora, the luminous body covers the end of the nose, like the headlight of an engine. The deep-sea "angler" or "sea-devil" has a rod-like barbel rising from its head and ending in luminous filaments, which are supposed to act as lures for other fishes. According to Gunther, fishes have frequently been taken from the stomach of the "angler" quite as large as itself. It is commonly from three to six feet long.

The little Melanocetus, which is illustrated here, is not quite four inches long, but contains in its stomach a fish seven and a half inches long, rolled up spirally into a ball. This fish is also remarkable for having a vertical mouth. According to Gunther, three specimens of the Saccopharynx (a deep-sea eel several feet long) were found floating with fishes in their stomachs which many times exceeded the length of their destroyers. The Plagyodus ferox is about six feet long and very ferocious. From the stomach of one were taken several octopods, crustaceans, a young brama, twelve young boar fishes, a horse mackerel, and one young of its own species. Opre peculiarity is that it has ribs symmetrically arranged the whole length of its abdomen. The Odontostomus atratus is a rapacious fish whose teeth are so large as to prevent its mouth from shutting. The specimen in the illustration has swallowed a cuttlefish, "whose breadth is much in excess of its own body." A remarkable peculiarity is that its

1.-Paroneirodes glomerosus.

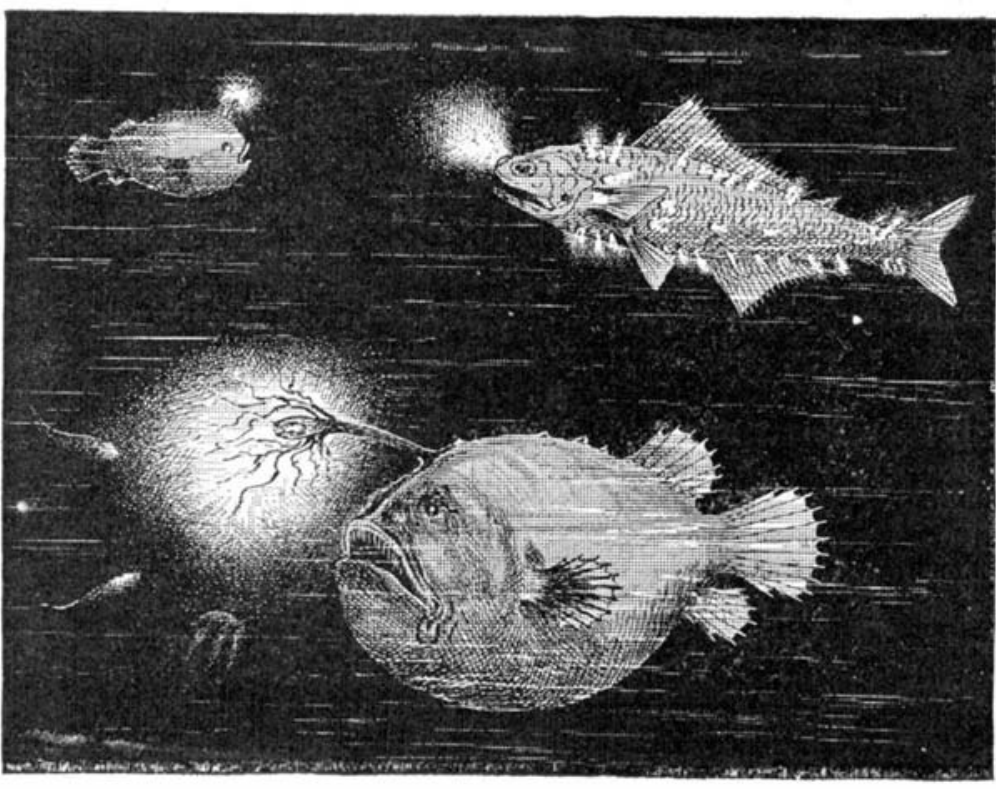

8. Corynolophus Reinhardtt.

SOME PHOSPHORESCENT FISHES OF THE DEEP SEA. eyes, which are lateral, can be turned to look upward. The specimen of the Chiasmodus niger here illustrated is six and five-eighths of an inch long, but contains a fish in its stomach which is ten and a half inches long. The stomach of the devourer is stretched as thin as gold-beater's skin. It has hooked teeth, and teeth which cross each other from opposite sides of the mouth The teeth of these rapacious fishes of the deep sea usually point backward. According to Gunther, the fish, after having seized its victim with its capacious and very movable jaws, partly presses it down as a snake would do, and partly draws itself over it. The prey is received into an œsophagus and stomach, the mem branes of which are extensible as an India-rubber pouch, and which, therefore, may "contain a body twice or thrice the size of the destroyer. The empty stomach is contracted and folded up, and projects but little below the abdomen."

The color of deep-sea fishes is commonly black or dark brown. But although it is claimed that light is essential to the formation of colors, some deep-sea fishes are scarlet in parts, or uniform red or rosy. Others are silvery white, while according to Alcock the Neocopelus is "one dazzling sheen of purple and silver and burnished gold, amid which is a sparkling constellation of luminous organs."

The bottom of the deep sea is apparently devoid of plant life except perhaps in the form of bacteria. There is, however, an abundance of slime comprising animalcules, which are constantly rained down from the upper

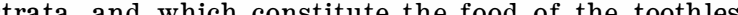
strata, and which constitute the food of the too cumscribed influence of environment, we here also find crabs, prawns, crayfish, shrimp, lobsters, mollusks, starfishes, sea-urchins, corals, sponges, protozoa, etc., which are not only identical in all essentials with shallowwater specimens, but also with specimens of the remotest geologic showing.

Much yet remains to be learned of the deep seas, for

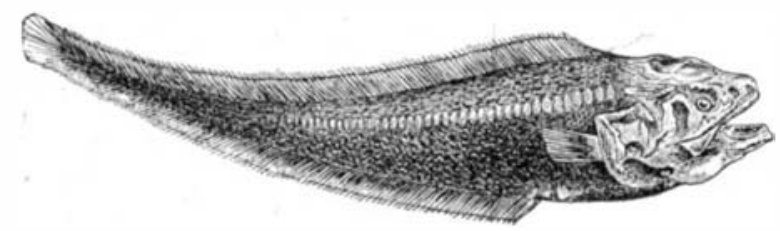

LAMPROGRAMMUS NIGER (ALCOCK).

Indian " Fire-fish" with row of luminous scales.

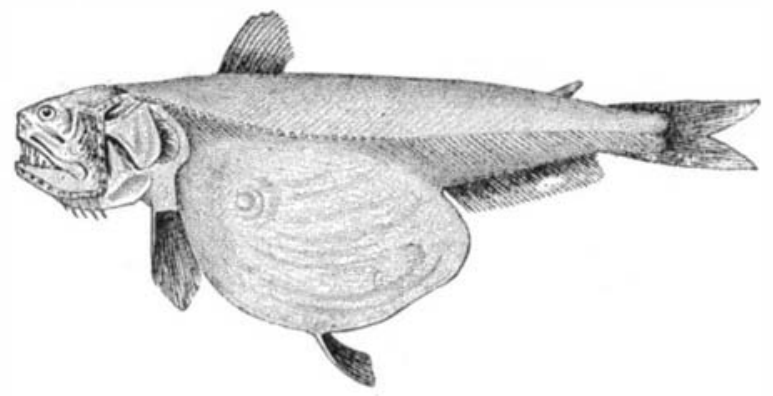

ODONTOSTOMUS HYALINUS (COCCO),

Fish containing cuttle-fish broader than itseif.

only within the last fifty years have they begun to be explored at all extensively.

A unique feature of a snowbound train recently was the setting up of telephonic communication between it and the outside world. The train became stalled in deep drifts in a small village some 25 miles from Buffalo. So deep was the snow that it was impossible for the passengers to leave the train. One of the passengers jocularly remarked that he would telephone home for his dinner. A telephone expert who was present heard the remark and afterward left the train, found a lineman and some wire in the village, and in two hours had a telephone installed in one of the cars. The instrument was connected to one of the long-distance lines, and for the fifteen hours the train was stalled it was kept in almost constant operation by the passengers, who talked easily with friends anywhere from 10 to 200 miles away.

Wood Preservative and Dry Rot Remedy.Dissolve 15 kilos of trinitrophenol in a vessel in 35 kilos of hot water, and after the solution obtained in this manner has almost cooled, gradually enter 20 kilos of soda lye of 15 degrees Be., with continued slow stirring. By the addition of dyestuffs any desired color can be produced. This preparation has an excellent antiseptic action, and is a radical remedy for the eradication or prevention of dry-rot, delaying the rotting or molding of wood most effectively.-Der Chemisch-Technische Fabrikant. 